\title{
Phylogeny and Physiology of Actinomycetes and Biogeochemical Parameters in Sediments of Eastern Mediterranean Sea
}

\author{
Ilknur Tuncer and Nihayet Bizsel
}

\begin{abstract}
In spite of high morphological and phylogenetic diversity, biotechnological and economic importance of actinomycetes, there is a limited number of studies in sediments of Eastern Mediterranean Sea, especially in relation with environmental parameters. The actinomycetes were isolated from deep-basins of Eastern Mediterranean Sea (72-1235 m depths) with regional variability. They were tested physiologically using commercial kits and found that they utilized proteins rather than carbohydrates. According to $16 \mathrm{~S}$ rRNA gene sequence analysis, highly diverse Streptomycetes strains with two of them representing new taxa and also the genera Nocardiopsis and Pseudonocardia were obtained. Geochemical parameters of the sediments together with enzymatic activity results of the strains underlined the nitrogen limitation in the area.
\end{abstract}

Index Terms-Actinobacteria, 16S rRNA genes, sediments, Eastern Mediterranean Sea.

\section{INTRODUCTION}

Actinomycetes are aerobic, nonmotile, and Gram-positive bacteria with high GC content in their DNA. They are very important due to their high diversity and production of secondary metabolites. However, discovery from terrestrial actinomycetes has declined recently and thus marine environment has been opened to research area.

Compared to cultivation-independent methods, cultivation-based studies are generally preferred for further studies such as production of secondary metabolites and determination of physiological characteristics needed in especially identification of new species [1], [2]. Although the Actinobacteria accounted minor part in 16S rRNA gene libraries of Mediterranean sediments [3], especially for Eastern Mediterranean Sea sediments as $4-28 \%$ of total sequence [4], they were highly isolated from the deep sediments of Eastern Mediterranean Sea in the previous culture-dependent study [5]. Furthermore, highly diverse and antibiotically active actinomycetes were also obtained in coastal zone of Turkish marine environments [6].

Since actinomycetes are biotechnologically and economically important bacteria and there is a limited number of phylogenetic studies in association with

Manuscript received November 21, 2016; revised March 23, 2017. This work was supported in part by the Scientific and Technological Research Council of Turkey (TUBITAK) and also Scientific Research Project Coordination Unit (BAP), Dokuz Eylul University under project no. COST 110Y193 and 2010.KB.FEN.014, respectively.

Ilknur Tuncer and Nihayet Bizsel are with Institute of Marine Sciences and Technology, Dokuz Eylul University, Turkey (e-mail: tuncerilik@gmail.com, nihayet.bizsel@deu.edu.tr). environmental parameters in the sediments of Eastern Mediterranean Sea (EMS) which is one of the most oligotrophic regions in the world [4]-[10], in the present study, it was aimed to isolate actinomycetes from sediments of EMS, to physiologically and phyogenetically analyze them and also to analyze biogeochemical parameters of EMS with regional variability.

\section{MATERIALS AND METHODS}

\section{A. Sediment Sampling and Analysis}

In the present study, sediment samples were taken from totally 11 stations with $72-1235 \mathrm{~m}$ depths of Eastern Mediterranean Sea for both bacterial isolation and sediment analysis (Fig. 1). While the stations $\mathrm{C} 1$ and $\mathrm{C} 2$ were located at the upper most North Aegean Sea, the stations C6-C8 were at the lower most South Aegean Sea. On the other hand, stations B1-B5 were between Lesvos Island and Karaburun in North Aegean Sea whereas the station C10 was near to Cyclades plateau at the center. The sediment samples were collected into sterile plastic bags, $40 \mathrm{ml}$ glass containers and sterile plastic cores for different processes and kept at $-20^{\circ} \mathrm{C}$ till the analysis.

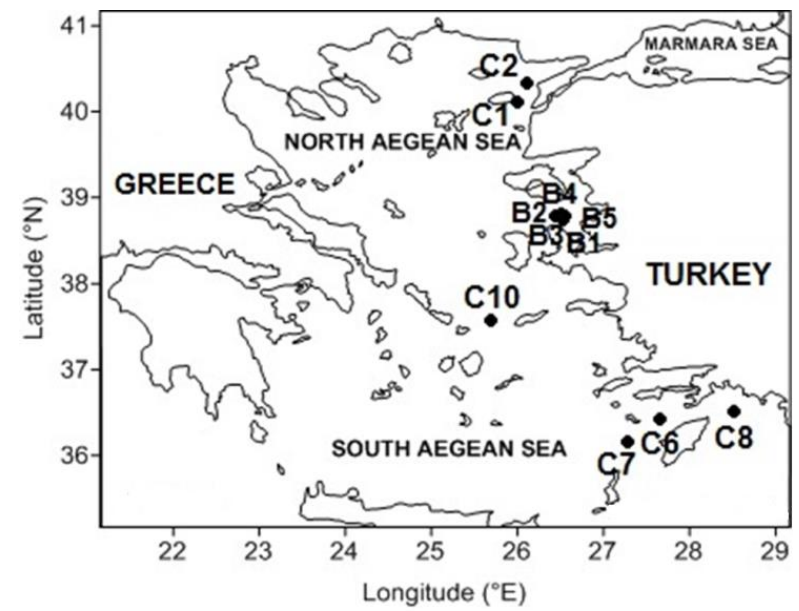

Fig. 1. Stations C $(1,2,6-8,10)$ and B (1-5) in Eastern Mediterranean Sea

The particle size of the sediments was determined by the sieve analysis and the hydrometer method for the larger and the finer particles, respectively according to standard test method for particle size analysis of soils D 422-63 issued by American Society for Testing and Materials [11].

Total and organic carbon and nitrogen contents (TC and TOC, TN and TON, respectively) were obtained using Carlo Erba NC2500 model CHN analyzer, on the other hand, total 
and organic phosphorus contents (TP and TOP, respectively) were measured spectrophotometrically [12].

\section{B. Bacterial Isolation and Physiological Analysis}

Isolation of bacteria was achieved using seven different sediment processing methods and two isolation media prepared with sterile seawater. The isolation media consisted of the following: M1, $18 \mathrm{~g}$ agar, $10 \mathrm{~g}$ starch, $4 \mathrm{~g}$ yeast extract, $2 \mathrm{~g}$ peptone, 1 liter sterile seawater; M2 (Difco $^{\mathrm{TM}}$ actinomycete isolation agar, modified), $22 \mathrm{~g}$ medium, $5 \mathrm{ml}$ glycerol, $500 \mathrm{ml}$ sterile sea water and $500 \mathrm{ml}$ distilled water. The isolation media M1 and M2 were used with or without six different antibiotics as cycloheximide $(100 \mu \mathrm{g} / \mathrm{ml})$, nystatin $(50 \mu \mathrm{g} / \mathrm{ml})$, polymixin B sulfate $(5 \mu \mathrm{g} / \mathrm{ml})$, rifampin $(5 \mu \mathrm{g} / \mathrm{ml})$, kanamycin sulfate $(5 \mu \mathrm{g} / \mathrm{ml})$, novobiocin $(25$ $\mu \mathrm{g} / \mathrm{ml})$.

Seven different sediment processing methods were performed. In the first processing method (a) [13], $10 \mathrm{ml}$ wet sediment sample were dried overnight and then $0.5 \mathrm{~g}$ dry sediment was aseptically spread in circular fashion onto the agar media. In the dry spot method (b) dry sediment was taken with sterile sponge and put clockwise on the agar media. In the third method (c) [14], $1 \mathrm{ml}$ wet sediment was diluted with sterile seawater $(1: 4)$ and then heated for 6 min at $55^{\circ} \mathrm{C}$. After vortexing for $30 \mathrm{~s}, 75-100 \mu \mathrm{l}$ was spread aseptically onto agar-based isolation media. In the fourth method (d) [15], wet sediment was heated for $15 \mathrm{~min}$ at $70^{\circ} \mathrm{C}$ and then spread aseptically on the agar surface in a circular fashion. In the fifth method (e) [16], wet sediment was kept for $30 \mathrm{sec}$ under UV and then spread aseptically in a circular fashion onto the agar media. In the sixth method (f) $1 \mathrm{ml}$ wet sediment sample was diluted with sterile seawater $(1: 1,1: 10$ and $1: 100)$ and then vortexed for $30 \mathrm{~s}$. Then, $75-100 \mu \mathrm{l}$ was spread aseptically onto agar-based isolation media. In the seventh method $(\mathrm{g})$ without processing, wet sediment sample was aseptically spread onto agar-based isolation media.

All plates were incubated at $26-28^{\circ} \mathrm{C}$ upto 2 months. The colonies were subcultured on M1 or M2 media and then the isolates were cryopreserved with $50 \%$ glycerol at $-20^{\circ} \mathrm{C}$.

All strains were also tested using API ZYM ${ }^{\circledR}$ (BioMérieux, Inc. Durham, USA) and BD BBL ${ }^{\mathrm{TM}} \mathrm{Crystal}^{\mathrm{TM}}$ GP ID (Becton Dickinson and Company, USA) commercial kits according to user's manuals.

\section{Nuclear DNA Extraction and 16S rRNA Amplification}

Genomic DNA of isolated bacteria was extracted with a commercial kit (Invitrogen, Carlsbad, CA) according to the user's manual for Gram-positive bacterial cell lysate.

The 16S rRNA genes were amplified from genomic DNA by PCR using the universal primer pairs of $\mathrm{FC} 27$ (5'-AGAGTTTGATCCTGGCTCAG-3') and RC1492 (5'-TACGGCTACCTTGTTACGACTT-3') and also the pairs of 63f (5'-CAGGCCTAACACATGCAAGTC-3') and $1387 \mathrm{r}$ (5'-GGGCGGWGTGTACAAGGC-3'). The 50 $\mu 1$ PCR mixture contained 20 to $50 \mathrm{ng}$ of DNA, One Taq Quik-Load 2X Master mix (New England Biolabs, Inc. Beverly, MA), 10 pmol of each primer (Fermentas, Thermo Fisher Scientific, Waltham, MA), and $10 \mathrm{mM}$ deoxynucleoside triphosphate mixture (Fermentas, Thermo Fisher Scientific, Waltham, MA). The PCR program consisted of 30 cycles of $94^{\circ} \mathrm{C}$ for $1 \mathrm{~min}, 55^{\circ} \mathrm{C}$ for $1 \mathrm{~min}$, and $72^{\circ} \mathrm{C}$ for $1 \mathrm{~min}$ followed by a final extension step at $72^{\circ} \mathrm{C}$ for $7 \mathrm{~min}$. Amplification products were examined by agarose gel electrophoresis.

\section{Sequencing and Phylogenetic Analysis}

Sequencing service was taken from Gene Research and Technology (RefGen, Turkey). For the phylogeny, all nucleotide sequences were analyzed using Geneious (version 6.1; Biomatters Ltd., NZ) and compared within the NCBI database (http://www.ncbi.nlm.nih.gov/) using the Basic Local Alignment Search Tool (BLAST). Phylogenetic analysis was performed using Mega [17] with 1000 bootstrap neighbor-joining method.

All those partial 16S rRNA gene sequences have been deposited into GenBank database (http://www.ncbi.nlm.nih.gov/GenBank/index.html) under the accession numbers KC815756-KC815772, KF366670, KF366671, KF366674, KF366679 and KF366682.

\section{RESUlts}

\section{A. Sediment Parameters}

Grain size analysis showed that the deep-basins had finest particles as expected. While the stations C1, B1, B3, B5 were sand and B2, B4 were sand-silt-clay, the stations C2, C6-C8, C10 were clayey silt (Table I). For the chemical contents of the sediments, the station $\mathrm{C} 1$ had the lowest carbon and phosphorus values whereas stations C6-C8 had the highest carbon values (Table I). On the other hand, the carbon ranges of the stations B1-B5 were 5.3-9.6\% and 1.0-3.3\% for TC and TOC, respectively as in between compared to the rest. While phosphorus contents were not changed among stations, except $\mathrm{C} 1$, the variation in nitrogen values was obvious (Table I) as indicating the nitrogen playing much more dynamic role in sediments.

TABLE I: THE SEDIMENT PARAMETERS FOR STATIONS IN EASTERN MEDITERRANEAN SEA

\begin{tabular}{ccccccccc}
\hline Stations & $\begin{array}{c}\text { Depth } \\
(\mathrm{m})\end{array}$ & Sediment type & $\begin{array}{c}\text { TC } \\
(\%)\end{array}$ & $\begin{array}{c}\text { TOC } \\
(\%)\end{array}$ & $\begin{array}{c}\text { TN } \\
(\%)\end{array}$ & $\begin{array}{c}\text { TON } \\
(\%)\end{array}$ & $\begin{array}{c}\text { TP } \\
(\%)\end{array}$ & $\begin{array}{c}\text { TOP } \\
(\%)\end{array}$ \\
\hline B1 & 104 & sand & 9.6 & 1.1 & 0.02 & BDL & 0.048 & 0.015 \\
B2 & 198 & sand-silt-clay & 5.3 & 1.7 & 0.24 & BDL & 0.032 & 0.017 \\
B3 & 159 & sand & 6.4 & 2.8 & 0.06 & BDL & 0.053 & 0.008 \\
B4 & 190 & sand-silt-clay & 5.4 & 1.0 & 0.02 & BDL & 0.038 & 0.010 \\
B5 & 106 & sand & 5.7 & 3.3 & 0.20 & 0.15 & 0.037 & 0.007 \\
C1 & 72 & sand & 2.9 & 0.6 & 0.94 & BDL & 0.011 & 0.004 \\
C2 & 522 & clayey silt & 5.0 & 2.8 & 0.02 & BDL & 0.033 & 0.016 \\
C6 & 703 & clayey silt & 15.3 & 9.0 & 0.57 & 0.21 & 0.026 & 0.011 \\
C7 & 1035 & clayey silt & 9.6 & 5.3 & 0.11 & BDL & 0.030 & 0.013 \\
C8 & 1235 & clayey silt & 17.9 & 1.6 & 0.38 & 0.01 & 0.028 & 0.011 \\
C10 & 661 & clayey silt & 4.4 & 1.9 & 0.30 & 0.12 & 0.030 & 0.016 \\
\hline C: 1046
\end{tabular}

TC: total carbon; TOC: total organic carbon; TN: total nitrogen; TON: total organic nitrogen; TP: total phosphorus; TOP: total organic phosphorus; BDL: below detection limit.

\section{B. Phylogeny and Physiology of Actinomycetes}


Totally 22 actinomycete strains were successfully isolated from mostly M1 and then M2 media and among seven sediment processing methods, the methods (a) and (f) which were overnight drying wet sediment and diluting wet sediment with sterile seawater were highly efficient.

The isolates generally showed high phosphatase (alkaline or acid), lipase or esterase, aminopeptidase activities (90\%, $81 \%$ and $68 \%$ of all isolates, respectively), in contrast to low enzymatic activities for carbon utilization such as glucosidase or galactosidase activities with $44 \%$ of isolates and also $15 \%$ averaged activity against related substrates for glucosaminidase, maltosidase, urase, trehalase, lactase, methyl glucosidase, sucrase, mannitol dehydrogenase, amylase, arabinase, fructokinase, glycerol kinase, glucuronidase, mannosidase, fucosidase and dehydrogenase. According to the average activity values for each station, the strains isolated from the station $\mathrm{C} 10$ showed the lowest activities whereas the highest glucosidase or galactosidase activities were obtained from stations C6-C8 (Table II). On the other hand, while the isolates from the station $\mathrm{C} 2$ gave the second lowest phosphates activity, the station $\mathrm{C} 1$ had the lowest glucosidase or galactosidase activities (Table II). Like this separation between closer stations $\mathrm{C} 1$ and $\mathrm{C} 2$, the isolates from deeper B stations (B2 and B4) showed lower activities compared to shallower B stations (B1, B3 and B5) (Table II). In fact, overall B stations had the highest aminopeptidase activity among all stations (Table II).

TABLE II: For EACH STATION, THE AVERAGE VALUES OF ENZYMATIC ACTIVITIES AGAINST THE RELATED SUBSTRATES

\begin{tabular}{ccccc}
\hline Stations & $\begin{array}{c}\text { Phosphatase } \\
\text { activity (\%) }\end{array}$ & $\begin{array}{c}\text { Aminopeptidase } \\
\text { activity }(\%)\end{array}$ & $\begin{array}{c}\text { Lipase or } \\
\text { esterase } \\
\text { activity }(\%)\end{array}$ & $\begin{array}{c}\text { Glucosidase or } \\
\text { galactosidase } \\
\text { activity }(\%)\end{array}$ \\
\hline B1 & 100 & 67 & 83 & 55 \\
B2 & 100 & 74 & 92 & 33 \\
B3 & 100 & 75 & 100 & 40 \\
B4 & 80 & 71 & 67 & 45 \\
B5 & 100 & 83 & 100 & 45 \\
C1 & 100 & 58 & 100 & 20 \\
C2 & 60 & 67 & 100 & 50 \\
C6 & 90 & 79 & 50 & 40 \\
C7 & 100 & 58 & 100 & 60 \\
C8 & 100 & 50 & 100 & 80 \\
C10 & 40 & 25 & 33 & 50 \\
\hline
\end{tabular}

The isolates were found highly affiliated with three families as Nocardiopsaceae, Pseudonocardiaceae and Streptomycetaceae (Table III). When the phylogenetic tree was constructed using nearly full 16S rRNA gene sequence of representative isolate for each nearest type strain, it was seen that the tree clearly supported those three families of the order Actinomycetales (Fig. 2).

The majority of the strains formed a highly diverse clade with members belonging to the genus Streptomyces highly isolated from stations B compared to stations C and there were also the genera Nocardiopsis and Pseudonocardia (Table III). When a limit of 98.5 to $99 \%$ was considered, as revised and proposed by [18], the Streptomyces strains
317CA6Y12 and 41BA4Y12 isolated from stations B4 and C6 had a probability of representing new taxa (Table III).

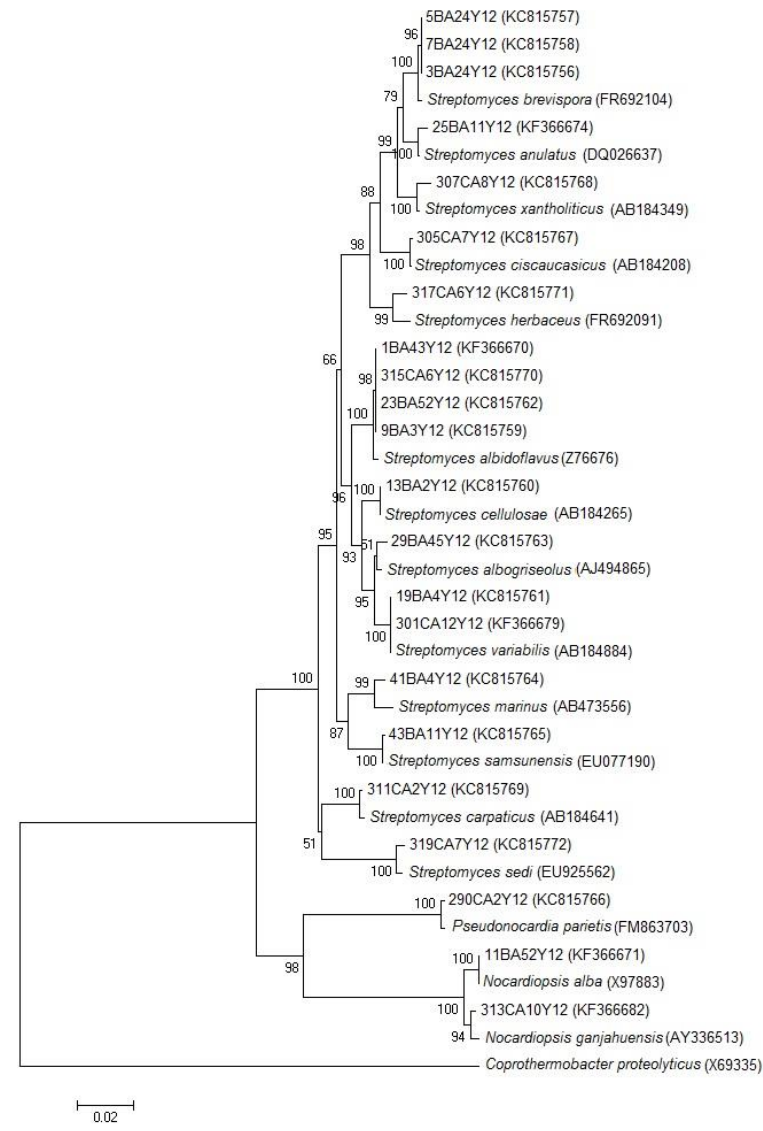

Fig. 2. For the order Actinomycetales, neighbor-joining distance tree constructed in Mega using partial 16S rRNA gene sequences. GenBank accession numbers were given in parentheses. Bootstrap values calculated from 1000 re-samplings were in percentage. Coprothermobacter proteolyticus was used to position the root.

TABLE III: THE LIST OF ISOLATES REPRESENTING THE CLASS ACTINOBACTERIA WITH THE NEAREST TYPE STRAINS ACCORDING TO THEIR 16S RRNA SEQUENCES

\begin{tabular}{|c|c|c|c|}
\hline Stations & Isolates & Nearest type strains & $\begin{array}{c}\text { Pairwise } \\
\text { similarity }(\%)\end{array}$ \\
\hline \multirow[t]{2}{*}{ B1 } & 25BA11Y12 & Streptomyces anulatus & 99.64 \\
\hline & 43BA11Y12 & Streptomyces samsunensis & 99.93 \\
\hline \multirow[t]{4}{*}{ B2 } & 3BA24Y12 & Streptomyces brevispora & 99.78 \\
\hline & 5BA24Y 12 & Streptomyces brevispora & 99.78 \\
\hline & 7BA24Y12 & Streptomyces brevispora & 99.78 \\
\hline & 13BA2Y12 & Streptomyces cellulosae & 100 \\
\hline B3 & 9BA3Y12 & Streptomyces albidoflavus & 99.71 \\
\hline \multirow[t]{4}{*}{ B4 } & 1BA43Y12 & Streptomyces albidoflavus & 99.71 \\
\hline & 29BA45Y12 & Streptomyces albogriseolus & 99.35 \\
\hline & 41BA4Y 12 & Streptomyces haliclonae & 98.60 \\
\hline & 19BA4Y12 & Streptomyces variabilis & 100 \\
\hline \multirow[t]{2}{*}{ B5 } & 11BA52Y12 & Nocardiopsis alba & 100 \\
\hline & 23BA52Y12 & Streptomyces albidoflavus & 99.71 \\
\hline $\mathrm{C} 1$ & 301CA12Y12 & Streptomyces variabilis & 100 \\
\hline \multirow[t]{2}{*}{$\mathrm{C} 2$} & 290CA2Y12 & Pseudonocardia parietis & 99.78 \\
\hline & $311 \mathrm{CA} 2 \mathrm{Y} 12$ & Streptomyces carpaticus & 99.71 \\
\hline \multirow[t]{2}{*}{ C6 } & 315CA6Y12 & Streptomyces albidoflavus & 99.71 \\
\hline & 317CA6Y12 & Streptomyces herbaceus & 98.93 \\
\hline \multirow[t]{2}{*}{$\mathrm{C} 7$} & 305CA7Y12 & Streptomyces ciscaucasicus & 99.93 \\
\hline & 319CA7Y12 & Streptomyces sedi & 99.57 \\
\hline $\mathrm{C} 8$ & 307CA8Y12 & Streptomyces xantholiticus & 99.34 \\
\hline $\mathrm{C} 10$ & 313CA10Y12 & Nocardiopsis ganjiahuensis & 99.57 \\
\hline
\end{tabular}




\section{Discussion}

The geochemical composition of the study area was generally in the range of Aegean Sea. In addition to the decrease in grain sizes with depth, the chemical contents of the sediments reflected the regional variability. The stations B closer to the coastal area as Lesvos Island, Izmir and Candarli Bays in North Aegean Sea, were distinguished from other stations. On the other hand, the geochemical variations among stations $\mathrm{C}$ were also seen. Although both stations $\mathrm{C} 1$ and C2 were located in the upper most North Aegean Sea having complex bottom topography and highly dynamic hydrographic conditions influenced by Aegean Sea and nutrient-rich Black Sea, the station C1 was near to the mouth of Dardanelle Strait carrying Black Sea water passing through Marmara Sea to Aegean Sea. While the stations C6-C8 were located in the lower most South Aegean Sea influenced by both Aegean Sea and oxygen-depleted and oligotrophic Levantine Sea, the station C10 was near to Cyclades plateau at the center. Furthermore, the stations C6-C8 had higher carbon contents than the previous results as $0.33-15.63 \%$ and $1.30-13.10 \%$ for TC, $0.22-6.76 \%$ and $0.42-0.99 \%$ for TOC in North and South Aegean Sea, respectively [4], [10], [19]-[23]. However, for the nitrogen contents, the station $\mathrm{C} 2$ had lower $\mathrm{TN}$ values than the previous $0.02-0.07 \%$ in North Aegean Sea [21] and the station C6 had higher TON than the previous $0.04-0.10 \%$ in South Aegean Sea [4].

In the study area, actinomycete diversity was found lower compared to previous studies in Eastern Mediterranean Sea. In the study of sediments in Cretan Sea, isolated actinomycetes were phylogenetically affiliated with the genera Arthrobacter, Blastococcus, Corynebacterium, Micromonospora, Pseudonocardia, Streptomyces [5]. However, in spite of high phylogenetic diversity in higher taxa in [5], Streptomyces strains were found more diverse in the present study. On the other hand, in addition to the isolation of alkaliphilic actinomycetes MA1-1 from sediments of Izmir Bay, Aegean Sea [8], much more diverse Streptomyces strains and one Nocardia alba strain were seen among 66 antimicrobially active strains of 261 actinomycetes isolated from the sediments in Turkish coasts of Black Sea, Aegean Sea and Mediterranean Sea [6].

In the present study, the isolation and diversity of actinomycetes were much higher from stations closer to coastal areas in North Aegean Sea compared to deeper stations in Eastern Mediterranean Sea. Moreover, the relation between enzymatic activities of actinomycetes and the chemical contents of the sediments in addition to the geographical variability was clearly seen in this study. Actinomycete strains isolated from the study area showed high aminopeptidase, phosphatase, lipase, esterase activities, in contrast to glucosidase, galactosidase, and even much lower trehalase, lactase, sucrase, amylase, arabinase, urease, etc. activities. In addition to a positive correlation between aminopeptidase activity and $\mathrm{N}$ limitation as an indication of the utilization of organic nitrogen for bacterial growth in the study of [24], it was also shown that bacterial biomass in the sediments of Aegean Sea displayed a positive correlation with the sedimentary protein concentration [7]. It was also given that carbohydrates were a reservoir of non-utilised organic carbon in oligotrophic deep-sea sediments [7]. Thus, in the present study, enzymatic activity results and organic nitrogen depletions in the sediments as underlying $\mathrm{N}$ limitation supported this protein utilization rather than carbohydrates and also reflected the geochemical effects on bacterial characteristics.

\section{CONCLUSION}

As a result, in this study, it was indicated that phenotypic and phylogenetic diversity of actinomycetes changed in accordance with geographical differences and environmental factors. For further studies i.e. identification of new species and production of secondary metabolites, the present study provided morphologically different actinomycete strains especially with probability of representing new taxa.

\section{REFERENCES}

[1] K. Zengler, G. Toledo, M. Rappe, J. Elkins, E. J. Mathur et al., "Cultivating the uncultured," P. Natl. Acad. Sci USA, vol. 99, pp 15681-15686, 2002.

[2] R. K. Pettit, "Culturability and secondary metabolite diversity of extreme microbes: expanding contribution of deep sea and deep-sea vent microbes to natural product discovery," Mar. Biotechnol., vol. 13, pp. 1-11, 2011.

[3] S. K. Heijs, A. M. Laverman, L. J. Forney, P. R. Hardoim, and J. D. van Elsas, "Comparison of deep-sea sediment microbial communities in the Eastern Mediterranean,” FEMS Microbiol. Ecol., vol. 64, pp. 362-377, 2008.

[4] P. N. Polymenakou, N. Lampadariou, M. Mandalakis, and A. Tselepides, "Phylogenetic diversity of sediment bacteria from the southern Cretan margin, Eastern Mediterranean Sea," Syst. Appl. Microbiol., vol. 32, pp. 17-26, 2009.

[5] A. Gärtner, M. Blümel, J. Wiese, and J. F. Imhoff, "Isolation and characterization of bacteria from the Eastern Mediterranean deep sea," Antonie Leeuwenhoek, vol. 100, pp. 421-435, 2011.

[6] K. Ozcan, S. C. Aksoy, O. Kalkan, A. Uzel, E. E. Hames-Kocabas, and E. Bedir, "Diversity and antibiotic-producing potential of cultivable marine-derived actinomycetes from coastal sediments of Turkey," $J$. Soils Sedim., vol. 13, no. 8, pp. 1493-1501, 2013.

[7] R. Danovaro, D. Marrale, N. Della-Croce, P. Parodi, and M. Fabiano, "Biochemical composition of sedimentary organic matter and bacterial distribution in the Aegean Sea: trophic state and pelagic-benthic coupling," J. Sea Res., vol. 42, pp. 117-129, 1999.

[8] E. E. Hames-Kocabas and A. Uzel, "Alkaline protease production by an actinomycete MA1-1 isolated from marine sediments," Ann. Microbiol., vol. 51, no. 1, pp. 71-75, 2007.

[9] I. Kouridaki, P. N. Polymenakou, A. Tselepides, M. Mandalakis, and K. L. Smith, "Phylogenetic diversity of sediment bacteria from deep Norteastern Pacific Ocean: A comparison with the deep Eastern Mediterranean Sea," Int. Microbiol., vol. 13, pp. 143-150, 2010.

[10] P. N. Polymenakou, S. Bertilsson, A. Tselepides, and E. G. Stephanou, "Links between geographic location, environmental factors and microbial community composition in sediments of the Eastern Mediterranean Sea," Microb. Ecol., vol. 49, pp. 367-378, 2005.

[11] ASTM Standard D422-63, Standard Test Method for Particle-Size Analysis of Soils, ASTM International, West Conshohocken, PA, 2007.

[12] R. Danovaro, "Total organic carbon, total nitrogen and organic phosphorus in marine sediments," Methods for the study of deep-sea sediments, their functioning and biodiversity, USA: CRC Press, 2009, pp. 13-22.

[13] T. J. Mincer, P. R. Jensen, C. A. Kauffman, and W. Fenical, "Widespread and persistent populations of a major new marine actinomycete taxon in ocean sediments," Appl. Environ. Microbiol., vol. 68, pp. 5005-5011, 2002.

[14] E. A. Gontag, W. Fenical, and P. R. Jensen, "Phylogenetic diversity of Gram-positive bacteria cultured from marine sediments," Appl. Environ. Microbiol., vol. 73, no. 10, pp. 3272-3282, 2007.

[15] M. Hayakawa, T. Sadaka, T. Kayiura, and H. Nonomura, "New methods for the highly selective isolation Micromonospora and Microbispora," J. Fermen. Bioeng., vol. 72, pp. 320-326, 1991. 
[16] O. A. Galatenko and L. P. Terekhova, "Isolation of antibiotic-producing actinomycetes from soil samples exposed to UV-light," Antibiot. I Khimioter, vol. 11, pp. 6-8, 1990.

[17] K. Tamura, D. Peterson, N. Peterson, G. Stecher, M. Nei, and S. Kumar, "MEGA5: molecular evolutionary genetics analysis using maximum likelihood, evolutionary distance, and maximum parsimony methods," Molecul. Biol. Evol., vol. 28, pp. 2731-2739, 2011.

[18] E. Stackebrandt and J. Ebers, "Taxonomic parameters revisited: Tarnished gold standards," Microbiol. Today, vol. 33, pp. 152-155, 2006.

[19] M. Aloupi, M. O. Angelidis, A. Gabriel, M. Karantanelli, M. Koulousaris et al., "Marine monitoring along the eastern coastal area of the Island of Lesvos, Greece during 2004," The Framework of Medpol III, vol. 9, no. 2, pp. 83-97, 2007.

[20] S. Aydin-Onen, F. Kocak, and F. Kucuksezgin, "Evaluation of spatia and temporal variations of inorganic nutrient species in the eastern Aegean Sea waters," Mar. Pol. Bull., vol. 64, pp. 2849-2856, 2012.

[21] N. Friligos and E. Krasakopoulou, "Chemical observations in the seawater and surface sediments of the Aegean Sea," CEST Proceedings, 2001, pp. 228-234.

[22] J. Hatzianestis, E. Sklivagou, and N. Friligos, "Hydrocarbons in surface sediments from the Northern Aegean sea," Rapp. Comm. Int. Mer Medit., vol. 35, pp. 264-265, 1998.

[23] M. Kostopoulou, M. Guida, A. Nikolaou, R. Oral, M. Trifuoggi et al., "Inorganic and organic contamination in sediment from Izmir Bay
(Turkey) and Mytilene Harbor (Greece)," Global NEST J., vol. 15, no. 1, pp. 57-68, 2013.

[24] A. Cunha and A. Almeida, "Inorganic nutrient regulation of bacterioplankton heterotrophic activity in an estuarine system (Ria de Aveiro, Portugal)," Hydrobiol., vol. 628, pp. 81-93, 2009.

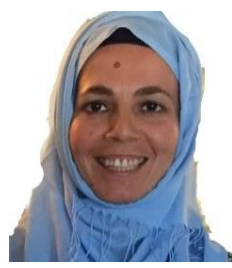

Ilknur Tuncer was born in Turkey, 1980. She received the BSc degrees in chemistry and genetics from Bogazici University, Turkey, the MSc degree in marine sciences from University of Wales, UK and the $\mathrm{PhD}$ degree in marine sciences from Dokuz Eylu University, Turkey in 2015. Her current reseach interests are marine environment, microbiology, phylogeny, and species-area relationship

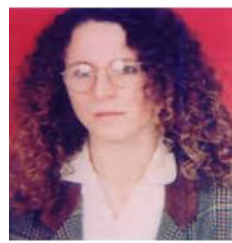

Nihayet Bizsel was born in Turkey. She received her $\mathrm{PhD}$ degree in marine sciences from Dokuz Eylul University, Turkey in 1996. Her current reseach interests are marine environment, and phytoplankton. 